\title{
CONTAMINANTS IN TERMS OF PESTICIDE RESIDUES IN SELECTED FISH SOURCES
}

\author{
Samah M. Ismael ${ }^{1}$, M.A. Abdallah., Sanaa M. El-Bendary ${ }^{1} \&$ Magda A. Rakha $^{2}$ \\ Food Science Dept., Fac. of Agric., Ain Shams Univ., Cairo, Egypt. \\ ${ }^{1}$ Home Economic Dept., Fac. of Specific Education, Ain Shams Univ., Cairo, Egypt. \\ ${ }^{2}$ Central Health Labs. For Laboratory Services, Ministry of Health.
}

\begin{abstract}
The problem at hand is dealing with the assessment of selected fish species with respect to their content of pesticide residues. The investigated fish include; Caranx, Red Mullet, Crabs, Clams, Sole of Qaroun, lake Sole of Bardawil lagoon and Catfish.

The results indicated the presence of 15 components of organochlorine pesticides, namely; $\alpha$-benzene hexachloride $(\alpha$-BHC), $\gamma$-benzene hexachloride $+\beta$-benzene hexachloride $(\gamma$-BHC $+\beta$-BHC), Heptachlor, Aldrin, Heptachorepoxide, $\gamma$-chlordane, $\alpha$-chlordane, 1,1-dichloro-2,2-bis (P-chlorophenyl) ethylene (P,P-DDE), Dieldrine, Endrin, 1,1-dichloro 2,2-bis (P-chlorophenyl) ethane (P,P-DDD), 1,1,1-trichloro-2,2-bis (P-chlorophenyl) ethane (P,P-DDT), Endosulfan sulfate, Methoxychlor and Endrin ketone.

Concentrations of chlorinated hydrocarbons in tissues, serve as good indicators of environmental loads. The determination of organochlorine residues became necessary since in high-polluted regions, the polychlorinated biphenyls (PCBs) are a point of discussion.

With respect to fish samples (Sole) collected from Bardawil lagoon, the obtained results indicated that none of the identified pesticides were detected in it. Subsequently, it could be stated that Bardawil lagoon is the best source of fish and is considered to be completely free from pollutants. On contrary Sole of Qaroun Lake contain six types of pesticides and the lowest frequently detected one was $8.49 \mu \mathrm{g} / \mathrm{Kg}$ as Heptachlor while the highest concentration of methoxychlor was $1268.68 \mu \mathrm{g} / \mathrm{Kg}$ in the same sample.

The residual concentration of the aforementioned pesticides varied within the tested fishes and Sole of Bardawil lagoon proved to be completely free from any residual amounts of the investigated pesticides as indicated and proved by statistical analysis, through the principal component and factorial analysis.
\end{abstract}

Key words : Pesticide residues, Organochlorine, Marketable fishes.

\section{INTRODUCTION}

Concentration of organochlorine insecticides and pesticides, DDT and its metabolites, total PCBs and 2,3,7,8-tetrachlordibenzo-pdioxin equivalents (TCDD-EQ) in composite samples of $10 \mathrm{spp}$. of edible fish collected at sites on 3 Canadian rivers, above and below dams. Mean levels of total PCBs, TCDD-EQ, DDT, and most of the other pesticides were greater in fish samples collected below the dams than in those from above. On the other hand, total level of PCBs ranged from 0.02 to $1.7 \mathrm{mg} / \mathrm{kg}$, while the concentration of TCDDEQ ranged from 2.4 to $71 \mathrm{mg} / \mathrm{kg}$ with the highest level in carp. TCDD-EQ concentration varied among fishes and locations and so, it is considered to be the critical contaminant. In most cases, as described by (Galal, 1991), dietary intakes of organochlorine and organophosphorous pesticides were well below the Acceptable Daily Intake (ADI) of the respective pesticide.

European eels (Anguilla anguilla), crucian carps (Carassius carassius) and catfish (Ictalu- rus nebulosus) were collected by Roche, (2000) from three coastal locations of the Vaccares lagoon (French National Nature Reserve of Camargue). Residues of organochlorine (OC) contaminants (i.e. capital sigma PCBs, $\gamma \mathrm{HCH}$, $\mathrm{HCB}$, dieldrin, $\mathrm{P}, \mathrm{P}-\mathrm{DDE}$ ) were determined in hepatic and muscular tissues, in order to compare geographical and seasonal distribution. Total exposure levels appeared to be more important in fatty fish such as eels than in crucian carps and catfish. The highest OC concentrations that detected in liver (capital sigma PCB) and in muscle $(\gamma \mathrm{HCH})$ were detected in Spring in some fish from a site located near a canal draining irrigation waters of rice fields. Correlations between the hepatic and muscular burdens of $\mathrm{OC}$ and condition factor or organo somatic indexes were infrequent and rather negative. Localization of lipid accumulation (neutral or polar lipids) depended on metabolic rates of different species and appeared related to the fish trophic level. 
Residue analysis showed that OC pesticides and their residues were generally more accumulated in carp adipose tissue (o,p' DDT; 4.217 ppm) and water bird adipose tissue ( $\beta$ BHC; $2.147 \mathrm{ppm}$ in coots, heptachlor epoxide; $2.744 \mathrm{ppm}$ in mallards). Also it was confirmed that OC pesticide residues were accumulated more in adipose tissues than in liver of fish and waterbirds. (Aya et al., 1997).

Bioassay tests were carried out by Trivedi \& Saksena (1999) to determine acute toxicity of an organophosphorus pesticide, "Nuvan" in freshwater catfish, Clarias batrachus. For the determination of $72 \mathrm{hr}$ LC sub (50) and 96hr LC sub (50), unweighted regression method was employed. The physico-chemical characteristics of test medium were quite constant during the experiment and the corresponding average of estimation was found to be $1.84 \pm 0.031 \mathrm{mg} / \mathrm{L}$ and $1.58 \pm 0.028 \mathrm{mg} / \mathrm{L}$. On exposure to "Nuvan", significant changes in movement, behavioral as well as body color were also observed.

PCBs concentrations in

\begin{tabular}{c|c|c|c}
\hline Fish samples & Scientific name & $\begin{array}{c}\text { District } \\
\text { market }\end{array}$ & $\begin{array}{c}\text { Quantity } \\
(\text { Kg) }\end{array}$ \\
\hline
\end{tabular}

1- Nile fish samples (Cairo)

\begin{tabular}{|c|c|c|c|}
\hline Caranx spp & Carangidae & Cairo & 5 \\
\hline \multicolumn{4}{|c|}{ 2- Sea fish and shellfish samples (Alexandria) } \\
\hline Red mullet & Mullus surmuletus & & 5 \\
\hline Crabs nei & portunus spp & & 8 \\
\hline $\begin{array}{l}\text { Um El-kholool } \\
\text { (Clams) }\end{array}$ & Guitar fish & $\begin{array}{c}\text { El- } \\
\text { manshia }\end{array}$ & 8 \\
\hline
\end{tabular}

3- Fish Lakes

\begin{tabular}{|c|c|c|c|}
\hline Sole, Common & Solea Vulgaris & $\begin{array}{c}\text { Qaroun } \\
\text { lake } \\
\text { Bardawil } \\
\text { lagoon }\end{array}$ & $\begin{array}{l}5 \\
5\end{array}$ \\
\hline Total & & & $10 \mathrm{Kg}$ \\
\hline
\end{tabular}

\section{4- Drainages (Giza)}

\begin{tabular}{l|c|c|c} 
Catfish & Clarias spp & $\begin{array}{c}\text { Abo- } \\
\text { rawash }\end{array}$ & 5 \\
\hline Total & $\mathbf{4 1 ~ K g}$ \\
\hline
\end{tabular}

* Three replicates were repeated through the work. twenty-two samples out of 45 of catfish from Wilson were equaled or exceeded the Food and Drug Administration (FDA) tolerance of $2.0 \mathrm{mug} / \mathrm{g}$ while the average of all the $45 \mathrm{sam}-$ ple was $2.6 \mathrm{mug} / \mathrm{g}$. Only 4 out of 36 samples catfish of Fleet Hollow had PCBs concentrations which equaled or exceeded $2.0 \mathrm{mug} / \mathrm{g}$ and the overall average was $1.0 \mathrm{mug} / \mathrm{g}$. Statistical analyses indicated PCBs concentrations decreased with increased distance from Fleet Hollow. (Dycus \& Lowery, 1986).

\section{MATERIALS AND METHODS}

\section{Materials}

The investigated fish sources were collected from the following areas:

A well known districts, such as Sole fish from Fayoum governorate and Bardawil lagoon

Abo Rawash drainage (Catfish); Giza governorate.

A random fish samples from different marketable areas in Cairo and Alexandria governorates that include Caranx for the former while Red mullet, Crabs, Clams for the latter one.

\section{Methods}

\section{Preparation of fish}

Fish samples were washed by plain water and scaling (Scrape off the scales) was performed starting at the tail and scraping toward the head. The entire length of fish belly was cut from the vent to the head to remove the intestines followed by cutting around the pelvic fins to get rid of them.

The pectoral fin was discarded by cutting just back of the collarbone followed by removing of head and tail. The Dorsal fin was also removed and the fish was thoroughly washed in cold running water. Tissues of the clean fish samples were minced and thoroughly mixed to be in a homogenized form for further analysis (Stephen \& Marcia, 1981).

\section{Pesticides residues}

Pesticides residues were identified according to Anonymous (1995) using the G.C mass apparatus available at Central labs. For Laboratory Services, National Research center was used under the following temperature program; i.e., Detector temperature was $260^{\circ} \mathrm{C}$ while $280^{\circ} \mathrm{C}$ was used for injection. The applied column was Hp5Ms and carrier gas was Helium. 
Oven program temperature for identification was adjusted at $50^{\circ} \mathrm{C}$ for zero time then increase to $160^{\circ} \mathrm{C}$ by 18 rate for zero time then to $240^{\circ} \mathrm{C}$ by 4 rate for zero time and finally be increased to $280^{\circ} \mathrm{C}$ by 20 rate for 3 $\mathrm{min}$. The total run time was about $31 \mathrm{~min}$. The method was based on full scan of library containing 340-pesticide item. The standards includes $\alpha . \mathrm{BHC}, \gamma . \mathrm{BHC}+\beta . \mathrm{BHC}$, Heptachlor, Aldrin, Heptachlor epoxide, $\gamma$.chlordane, a.chlordane, P,P-DDE, Dieldrin, Endrin, P,PDDD, P,P-DDT, Endosulfan sulfate, Methoxychlor and Endrin ketone.

\section{Statistical analysis}

The principal component analysis was applied according to Jollife (1986), Martens \& Russwurn (1983).

The level of significance is accepted as being $\mathrm{P} \leq 0.05$ (unless otherwise stated). The SAS computer program was applied according to Helwing (1983) using the Pentium IV/3.06GHz Satellite Laptop, available at Prof. Dr. M.A. Abdallah, Food Sci. Dep., Fac. of Agric. Ain Shams Univ. Other statistical analysis in terms of degree of significance, $\mathrm{F}$ ratio, $\mathrm{T}$ values and correlation coefficient as well as standard error and standard deviation were also performed when needed using the "CSS" computer program as described by Statsoft (1991).

\section{RESULTS AND DISCUSSION}

\section{Levels of pesticide in Nile fish, Sea fish and Shellfish samples}

Contaminant matters as a group of pollutant materials have a long history and had been recorded early during the Roman Impire. Now, such problem has just become a major one during the last two decades. Subsequently, it is of great importance to look at contaminant matters, especially pesticides that can be introduced to the environment or to the natural water sources as well as fish and fish products. It is of importance to notify that the widespread distribution of organochlorine pesticide residues as contaminants in the ecosystem is an established fact. They can be transported for many thousands of kilometers far from the application place. In Egypt, researches confirmed the presence of several types of pesticides in fish, water and sediments. Moreover, lindane and DDT were detected and estimated by Abdel Gawaad et al., (1989), in rainwater collected from Cairo, Alexandria, Kalubia and Ismailia governorates.

Fish was found to contain considerable amounts of organochlorine pesticides (Askar, 1980); and their concentrations in fish were much higher than those found in water. On the other hand, Moilanan et al., (1986) stated that fish had long been contaminated by organochlorine pesticides and fish-liver-oils were also reported to contain considerable amounts of these compounds. On contrary, Organophosphorous pesticides are less persistent than organochlorines (Finkel, 1990 brganochlorine residues of both industrial and agricultural origin could be accumulated because of their lipophilic character and persistence in the aquatic food chain from waterplankton fish to the sea mammals. Concentrations of chlorinated hydrocarbons in tissues, serve as good indicators of environmental loads. The determination of organochlorine residues became necessary since in highpolluted regions, the PCBs are a point of discussion, in particular with respect to diseased seals in the North Sea in 1988 and the dying of stripe dolphins in the Mediterranean in summer 1990. Evaluation of the reasons demonstrated significant geographical differences in both level and pattern of the contaminants analyzed, thus giving an insight into the global distribution of organochlorine pollution. (Vetter \& Luckas, 1990).

Identities of organochlorine residues that found in the investigated fresh samples collected from Cairo governorates are given in Table (1). Analysis of the data shows that in some fish samples; concentrations of the tested organochlorine residues were high than the sensitive detectable level that required for GC technique. The other investigated fish contained varying levels of the same pesticide residues and the highest value was found for endosulfan sulfate $(152.73 \mu \mathrm{g} / \mathrm{Kg})$ followed by heptachlor epoxide $(139.32 \mu \mathrm{g} / \mathrm{Kg})$ in Nile Caranx fish samples. However, the detectable concentration of organochlorine residues was generally varied greatly. For instance, the minimum value of endrin ketone was $38.73 \mu \mathrm{g} / \mathrm{Kg}$ while the maximum was $152.73 \mu \mathrm{g} / \mathrm{Kg}$ for endosulfan sulfate while the total of DDT (P,P-DDE, P,P-DDD and P,PDDT) for the same sample was $75.02 \mu \mathrm{g} / \mathrm{Kg}$. 
Table 1: Organochlorine residues in the oil content of Nile fish and Shellfish samples calculated as $(\mu \mathrm{g} / \mathrm{Kg})$.

\begin{tabular}{lcccc}
\hline \multirow{2}{*}{$\begin{array}{c}\text { Identified Pesti- } \\
\text { cides }\end{array}$} & $\begin{array}{c}\text { Nile } \\
\text { Fish }\end{array}$ & Sea fish & \multicolumn{2}{c}{ Shellfish } \\
\cline { 2 - 5 } Caranx & $\begin{array}{c}\text { Red } \\
\text { Mullet }\end{array}$ & Crabs & $\begin{array}{c}\text { Um El- } \\
\text { kholool }\end{array}$ \\
\hline$\alpha$. BHC & 48.99 & - & - & 2.55 \\
$\gamma$. BHC+ $\beta . B H C$ & 119.08 & - & - & - \\
Heptachlor & 48.28 & - & - & 5.46 \\
Aldrin & 127.38 & - & - & - \\
Heptachlor epoxide & 139.32 & 10.46 & 3.03 & 19.67 \\
$\gamma$. chlordane & - & 9.83 & 18.03 & 37.10 \\
$\alpha . c h l o r d a n e$ & 69.27 & - & - & - \\
P.P-DDE & 75.02 & - & 59.22 & 111.51 \\
Dieldrin & 53.60 & 7.52 & 18.64 & 32.41 \\
Endrin & - & 13.22 & 33.00 & - \\
P.P-DDD & - & 28.93 & 382.03 & 46.91 \\
P.P-DDT & - & - & - & 59.82 \\
Endosulfan sulfate & 152.73 & - & 15.57 & 76.79 \\
Methoxychlor & - & - & - & 279.56 \\
Endrin ketone & 38.73 & - & 3.71 & - \\
\hline & & & & \\
\hline
\end{tabular}

and DDT residues are more strongly accumulated (up to ca 2 folds) by $S$. glomerata than by $M$. liliana. This result contrasts with observations from a previous study (Wilcock et al., 1993) in which it was shown that lipid-normalised chlordane concentrations accumulated more rapidly in a surface deposit feeding shellfish (M. liliana) than in a filter feeder $(A$. stutchburyi), but tended to have similar equilibrium values.

The organochlorine residues were analyzed in sea fish and shellfish samples collected from Alexandria governorate as given in Table (1) and Fig. (1). Analysis of the data proved the predominance of heptachlor epoxide in all fish and shellfish samples, followed by dieldrin. In such previous case the maximum level of heptachlore epoxide was 139.32, $19.67 \mu \mathrm{g} / \mathrm{Kg}$ in Caranx and Um El-kholool, respectively, correlated to $10.46 \mu \mathrm{g} / \mathrm{Kg}$ in Red mullet sample while the mini-

Cumulative data of the aforementioned results showed the followmum level $3.03 \mu \mathrm{g} / \mathrm{Kg}$ was found in the Crabs as seen in Table (1).

ing main points:

- Heptachlor was found in Caranx fish collected from Cairo governorat $48.28 \mu \mathrm{g} / \mathrm{Kg}$. However, acute oral LD50 for male rate is $67 \mathrm{mg} \mathrm{Kg}$ as given in the Vetter \& Luckas, (1990).

- $\gamma . \mathrm{BHC}+\beta . \mathrm{BHC}$ was clearly present in Caranx fish samples $119.08 \mu \mathrm{g} / \mathrm{Kg}$.

- The $53.60 \mu \mathrm{g} / \mathrm{Kg}$ value for dieldrin was identified in fish market of Cairo governorate.

It is of interest to shed light upon the research carried out by Burggraaf et al., (1994), who identified the levels $(\mu \mathrm{g} / \mathrm{g}$ lipid) of nine

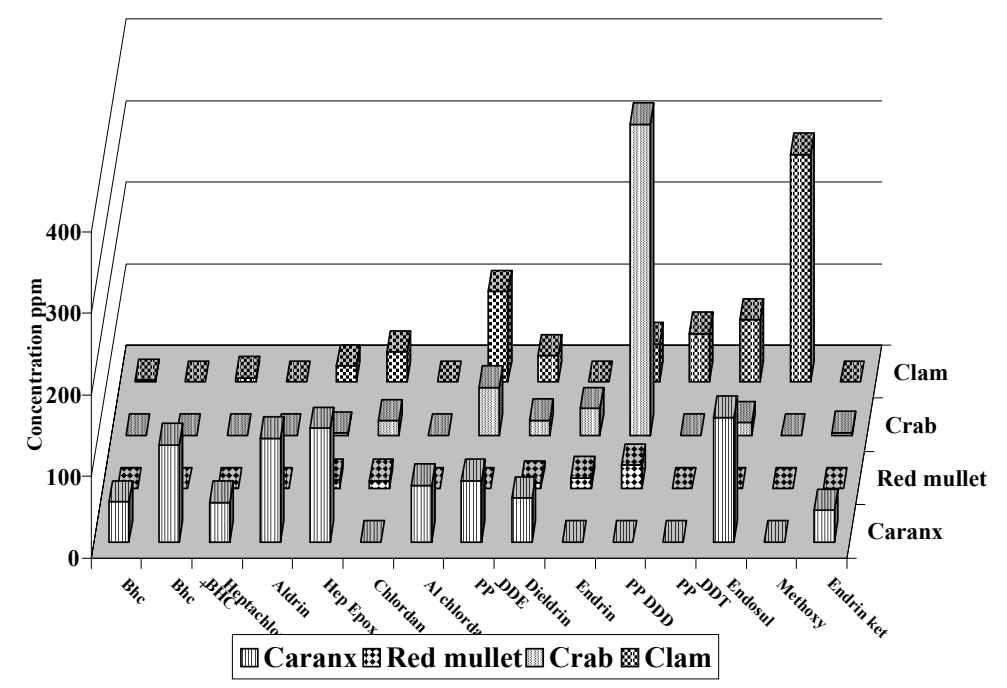

Fig. 1: Comparative trend between organochlorine residues $(\mu \mathrm{g} / \mathrm{kg} \mathrm{w.w})$ in the oil content of different fish sources

PCB congeners, P,P-DDD,

P,P-DDE, chlordanes (expressed as technical chlordane equivalents) and dieldrin in Waikareao Estuary biota species. Concentrations of $\Sigma$ PCB, $\Sigma$ DDT (sum of P,P-DDT, P,P-DDD and $\mathrm{P}, \mathrm{P}-\mathrm{DDE})$, total chlordane and dieldrin in biota (lipid and dry weight basis) as compared with sediment values from the same studies. PCB

The maximum levels of dieldrin were recorded in Um El-kholool from El-manshia area; being, $32.41 \mu \mathrm{g} / \mathrm{Kg}$ while the minimum levels were $7.52 \mu \mathrm{g} / \mathrm{Kg}$ for Red mullet. $\alpha$-BHC recorded $2.55 \mu \mathrm{g} / \mathrm{Kg}$ only in Um El-kholool, $\gamma$ chlordane recorded $9.83 \mu \mathrm{g} / \mathrm{Kg}$ in fresh Red mullet fish sample up to $37.10 \mu \mathrm{g} / \mathrm{Kg}$ in Um ElKholool shellfish. 
Regarding the identified P,PDDE pesticide values obtained were 59.22 and $111.51 \mu \mathrm{g} / \mathrm{Kg}$ in Crabs and Um El-kholool (Clam) shellfish respectively. P,P-DDD concentration was too high being 382.03 in Crabs and $46.91 \mu \mathrm{g} / \mathrm{Kg}$ in Clam El-Manshia while the lowest value was $28.93 \mu \mathrm{g}$ $/ \mathrm{Kg}$ in Red mullet. P,P-DDT was found only in Clam collected from El-Manshia with a level of $59.82 \mu \mathrm{g}$ $/ \mathrm{Kg}$. Similar finding was noticed in methoxychlor $279.56 \mu \mathrm{g} / \mathrm{Kg}$.

Regarding endrin pesticides, experiments proved that it was found in two cases and the highest value was $33.00 \mu \mathrm{g} / \mathrm{Kg}$ in Crab that represent 2.5 folds that of Red mullet sea fish, although endrin ketone was found in Crabs 3.71 in fresh fish.

Cumulative data are presented in Table (1) from which the following main points can be inferred:

- Shellfish samples contain the highest numbers of pesticide especially Um El-kholool and followed Crabs; showing 10 and 8 of the tested organochlorine pesticides as seen in Fig (2).

- Sea fish samples contain the few numbers of pesticides reached 5 in Red mullet.

- The highest concentration was noticed for methoxychlor, P,P-DDE, Endosulfan Sulfate, P,P-DDD and P,P-DDT.

\section{Level of pesticide in Sole fish and Catfish samples}

Pesticide residues that were determined in fish samples collected from different sources namely Qaroun Lake, Bardawil lagoon and drainage Abo-rawash are shown in Table (2). Concentrations of the given pesticides varied and that detected in the Catfish sample came in the first order followed by Sole of Qaroun Lake.
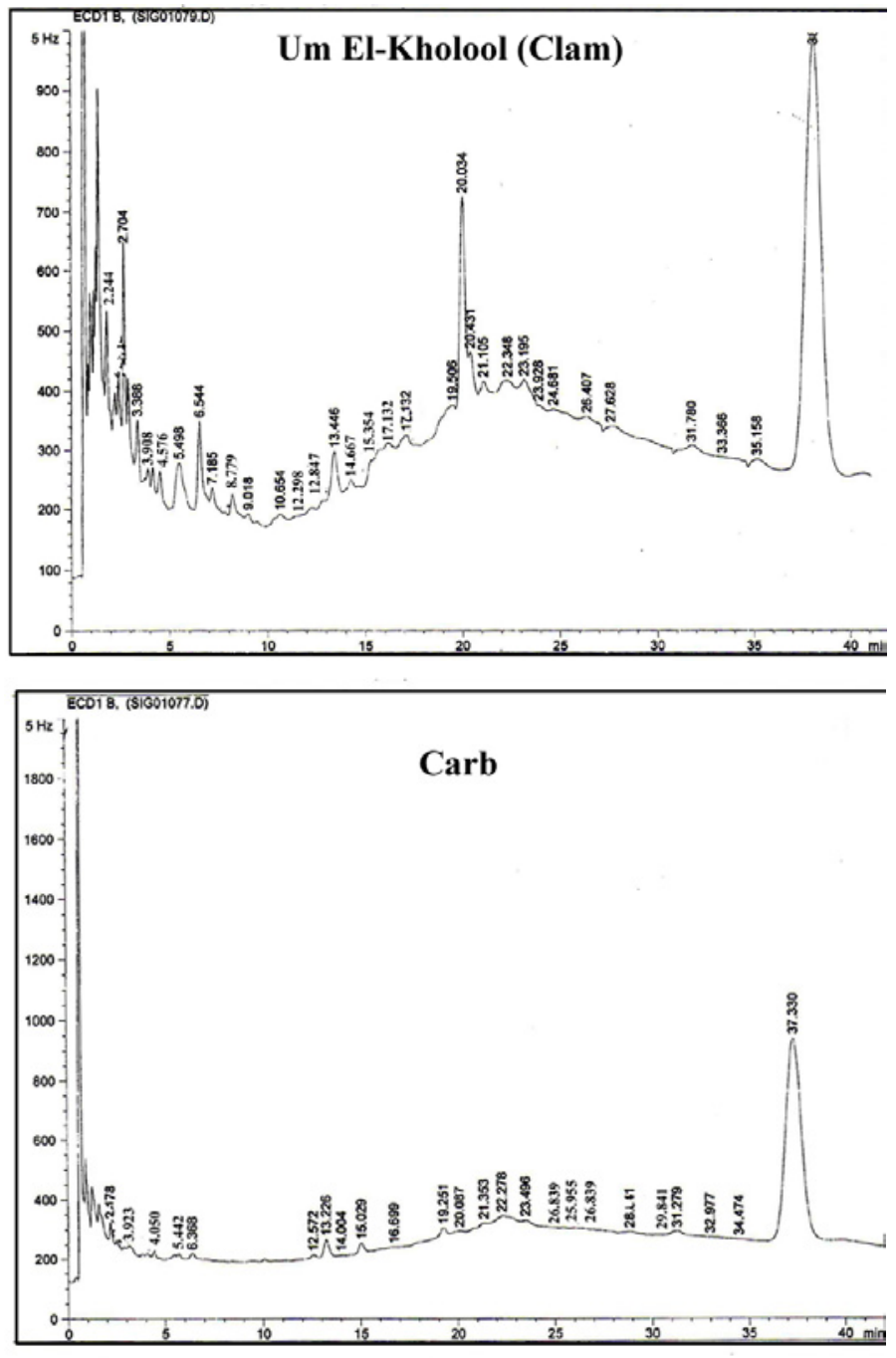

Fig. 2: GC chromatogram of the identified pesticide residues in the investigated shellfish samples

Table 2: Organochlorine residues $(\mu \mathrm{g} / \mathrm{Kg})$ in the tested fish collected from different sources

\begin{tabular}{|c|c|c|c|}
\hline \multirow[b]{2}{*}{ Identified Pesticides } & \multicolumn{2}{|c|}{ Sole } & \multirow[b]{2}{*}{$\begin{array}{c}\text { Drainage } \\
\text { Catfish }\end{array}$} \\
\hline & $\begin{array}{c}\text { Lake } \\
\text { Qaroun }\end{array}$ & $\begin{array}{c}\text { Lagoon } \\
\text { Bardawil }\end{array}$ & \\
\hline$\alpha . \mathrm{BHC}$ & - & - & 320.79 \\
\hline$\gamma \cdot \mathrm{BHC}+\beta \cdot \mathrm{BHC}$ & 10.29 & - & 399.68 \\
\hline Heptachlor & 8.49 & - & 599.39 \\
\hline Aldrin & - & - & - \\
\hline Heptachlor epoxide & 70.58 & - & 321.68 \\
\hline$\gamma$. chlordane & - & - & 352.85 \\
\hline$\alpha$. chlordane & - & - & 260.96 \\
\hline P.P-DDE & - & - & 195.72 \\
\hline Dieldrin & - & - & 138.09 \\
\hline Endrin & 624.15 & - & 174.08 \\
\hline P.P-DDD & - & - & - \\
\hline P.P-DDT & - & - & 535.54 \\
\hline Endosulfan sulfate & 112.02 & - & - \\
\hline Methoxychlor & 1268.68 & - & - \\
\hline Endrin ketone & - & - & - \\
\hline
\end{tabular}


With respect to fish sample (Sole) collected from Bardawil lagoon Table (2) indicated that none of the identified pesticides were detected in the fish Sole collected from such source. Subsequently, it could be stated that Bardawil lagoon is the best source of fish and is considered to be completely free from pollutants as shown in Fig (3).

On the contrary, Sole of Qaroun Lake contain six types of pesticides and the most frequently detected one was methoxychlor was $1268.68 \mu \mathrm{g} / \mathrm{Kg}$, while that of Endrin was $624.15 \mu \mathrm{g} / \mathrm{Kg}$ followed by endosulfan sulfate $112.02 \mu \mathrm{g} / \mathrm{Kg}$, heptachlor epoxide $70.58 \mu \mathrm{g} / \mathrm{Kg}, \gamma-$ $\mathrm{BHC}+\beta-\mathrm{BHC} 10.29 \mu \mathrm{g} / \mathrm{Kg}$ and 8.49 $\mu \mathrm{g} / \mathrm{Kg}$ in heptachlor. By analyzing the fish samples that were collected from drainage, the same Table indicated that the maximum and minimum levels of the identified pesticides were $599.39 \mu \mathrm{g} / \mathrm{Kg}$ (heptaclor), $138.09 \mu \mathrm{g} / \mathrm{Kg}$ (dieldrin) respectively as illustrated in Fig. (4).

With respect to Catfish sample, the concentrations of organochlorine pesticides were present in the following descending order: P,P-DDT $(535.54 \mu \mathrm{g} / \mathrm{Kg})$, $\gamma$-BHC $+\beta$-BHC $(399.68 \mu \mathrm{g} / \mathrm{Kg})$, $\gamma$-chlordanel $(352.85 \mu \mathrm{g} / \mathrm{Kg})$, heptachlor epoxide $(321.68 \mu \mathrm{g} / \mathrm{Kg}), \alpha$ chlordane $(260.96 \mu \mathrm{g} / \mathrm{Kg})$, P.PDDE $(195.72 \mu \mathrm{g} / \mathrm{Kg})$ and endrin $(174.08 \mu \mathrm{g} / \mathrm{Kg})$.

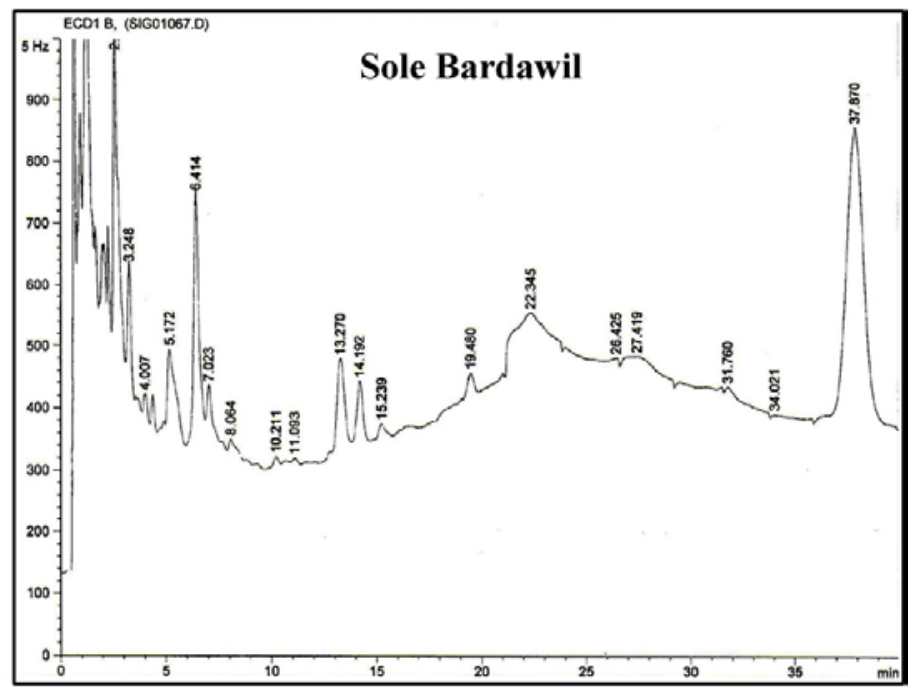

Fig. 3: GC chromatogram of the identified pesticide residues in the Sole of Bardawil lagoon

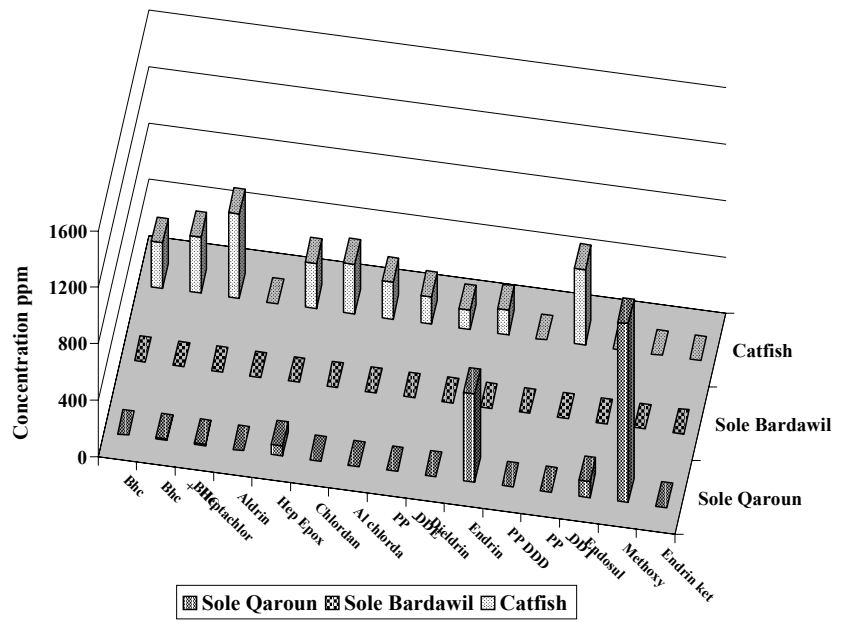

Fig. 4: Comparative trend between organochlorine residues $(\mu \mathrm{g} / \mathrm{kg} \mathrm{w} . \mathrm{w})$ in the oil content of Sole and Catfish samples

From the aforementioned results, the levels of pesticide residues differed greatly among the fish samples of the selected governorates. This may be due to the fact that the concentration of organochlorine residues in fish depends on environmental conditions, level of exposure, nature of pesticide and its solubility, fish species and its ability to excrete the compound. Organochlorine pesticides even if banned, can still be detected in fish because of their ability to persist for several years and to accumulate in aquatic organisms.

Statistical analysis of the pesticide residues in the tested fish samples was performed by principal components. The data was given

in Table (3). The percentage of total variance with the tested pesticides as well as the cumulative percentage indicated that four out of 15 pesticide residues accumulated $97.70 \%$ as follows; $\alpha$. BHC 57.60, $\gamma$. BHC $+\beta$. BHC 76.70, Heptachlor 92.20 and Aldrin 97.70.

When the principal component was concerned within the investigated fish samples in relation to the identified pesticide residues, statistical analyses given in Table (4) proved that Caranx (Cairo governorate) came in the first order with a total accumulation of 37.50 $\%$ of the most frequently detected pesticide residues. In case of sea fish and shellfish, the data of the same Table proved that the proportion of the identified pesticides was 0.316 in Red mullet, 0.184 in Crabs and 0.062 in Clam. 
Table 3: Statistical analysis in terms of principal components within the tested pesticides in relation to fish collected from different sources.

\begin{tabular}{|c|c|c|c|c|c|c|}
\hline \multirow{3}{*}{ Pesticide residues } & \multicolumn{6}{|c|}{ Principal components } \\
\hline & \multirow{2}{*}{ PC1 } & \multirow{2}{*}{ PC2 } & \multirow{2}{*}{ Eigenvalue } & \multirow{2}{*}{ Proportion } & \multicolumn{2}{|c|}{ Cumulative } \\
\hline & & & & & Value & $\%$ \\
\hline$\alpha . \mathrm{BHC}$ & -0.339 & 0.019 & 8.6351 & 0.576 & 0.576 & 57.60 \\
\hline$\gamma . \mathrm{BHC}+\beta . \mathrm{BHC}$ & -0.336 & -0.066 & 2.8691 & 0.191 & 0.767 & 76.70 \\
\hline Heptachlor & -0.337 & 0.062 & 2.3309 & 0.155 & 0.922 & 92.20 \\
\hline Aldrin & -0.005 & -0.580 & 0.8171 & 0.054 & 0.977 & 97.70 \\
\hline Heptachlor epoxide & -0.322 & -0.135 & 0.3458 & 0.023 & 1.000 & 100 \\
\hline$\gamma$. chlordane & -0.332 & 0.126 & 0.0021 & 0.000 & 1.000 & 100 \\
\hline$\alpha . c h l o r d a n e$ & -0.337 & -0.047 & 0.0000 & 0.000 & 1.000 & 100 \\
\hline P,P-DDE & -0.297 & -0.050 & 0.0000 & 0.000 & 1.000 & 100 \\
\hline Dieldrin & -0.333 & -0.087 & 0.0000 & 0.000 & 1.000 & 100 \\
\hline Endrin & -0.004 & 0.068 & -0.0000 & -0.000 & 1.000 & 100 \\
\hline P,P-DDD & 0.079 & 0.169 & -0.0000 & -0.000 & 1.000 & 100 \\
\hline P,P-DDT & -0.333 & 0.113 & -0.0000 & -0.000 & 1.000 & 100 \\
\hline Endosulfan sulfate & 0.076 & -0.483 & -0.0000 & -0.000 & 1.000 & 100 \\
\hline Methoxychlor & 0.094 & 0.035 & -0.0000 & -0.000 & 1.000 & 100 \\
\hline Endrin ketone & 0.002 & -0.572 & -0.0000 & -0.000 & 1.000 & 100 \\
\hline
\end{tabular}

However, this simply means that accumulation of pesticides in shellfish is lower than the other tested sea fish. Both of Sole of Quaron lake and Catfish indicated a proportion level of 0.050 and 0.012 respectively out of the identified pesticides.

Experiments proved clearly that Sole samples collected from Bardawil lagoon are completely free from any of the identified pesticides.

A freshwater edible catfish; Clarias batrachus (Linn.), was exposed to sublethal concentrations of two different groups of pesticides-carbaryl, a carbamate and phorate, and organophosphorus $(\mathrm{OP})$ pesticide - for 24, 72, 120 and 168 hours. The alterations and the disorders of carbohydrate metabolism were studied in the serum. Serum glucose, alkaline phosphatase and bilirubin levels increased with both tested pesticides throughout the exposure period. The results indicate also that the carbohydrate metabolism was adversely affected by both the pesticides, as evidenced in the serum of the fish (Jyothi \& Narayan, 1999).
Table 4: Statistical analysis in terms of principal components within the different fish sources in relation to the identified pesticide residues

\begin{tabular}{lccccc}
\hline \multicolumn{1}{c}{ Fish } & \multicolumn{5}{c}{ Principal component } \\
\cline { 2 - 6 } samples & PC1 & PC2 & Eigenvalue & Proportion & Cumulative \\
\hline $\begin{array}{l}\text { Nile fish samples } \\
\text { Caranx }\end{array}$ & 0.393 & 0.002 & 2.2527 & 0.375 & $\begin{array}{l}0.375 \\
=37.5 \%\end{array}$ \\
\hline $\begin{array}{l}\text { Sea fish and shellfish } \\
\begin{array}{l}\text { Red } \\
\text { mullet }\end{array}\end{array}$ & -0.446 & -0.481 & 1.8977 & 0.316 & 0.692 \\
$\begin{array}{l}\text { Crabs } \\
\text { Clam }\end{array}$ & -0.468 & -0.459 & 1.1010 & 0.184 & 0.875 \\
\hline $\begin{array}{l}\text { Sole Lake } \\
\text { Qaroun }\end{array}$ & -0.377 & 0.518 & 0.3749 & 0.062 & 0.938 \\
\hline $\begin{array}{l}\text { Drainage } \\
\text { Catfish }\end{array}$ & 0.369 & -0.088 & 0.0741 & 0.012 & 1.000 \\
\hline
\end{tabular}

Other reasons that explain the different levels of pesticide residue in the investigated fish samples are:

\section{Log-normal distribution of contaminants}

The potential health effects of environmental contaminants in food stuffs have become a concern among communities because of the presence of environmental contaminants in the Arctic ecosystem. Over the last 
10 years, there has been considerable effort to monitor the level of contaminants in fish and wildlife collected from different regions in Northern and Arctic Canada. Chan (1998). A significant percentage of the foods had contaminant levels exceeding the guidelines used by Health Canada for market food consumed by the "southern" populations. Mathematic modeling of the distributions of the data showed that contaminant levels in most food groups are log-normally distributed and have a typical coefficient of variation of about $100 \%$.

\section{Long-range atmospheric pattern and threshold effect.}

Environmental contaminants such as organochlorines are found in the Arctic environment as a result of long-range atomospheric and oceanic transport and local mining activities (Barrie et al., 1992). The potential health effect on Indigenous peoples is a concern because humans are at the top of the food chain and some of these pollutants are known to bioaccumulate (Muir et al., 1992). Moreover, both dietary exposure assessment and dosimetry studies have shown that people of some northern and Arctic communities may have elevated levels of contaminant exposure (Chan et al., 1997).

Fish fillets and shucked oysters were analyzed by Goodman et al., (1999) for selected organochlorine pesticides, polychlorinated biphenyl (PCB) congeners, and metals. Most contaminants were below water and sediment quality guidelines designed to protect aquatic life, and contaminant concentrations in oysters were low. Threshold effect levels were exceeded for some organochlorine pesticides and PAHs in some sediment samples, but all values measured were below probable effect levels. The only organochlorine pesticide detected in filets from seven fish was $3.2 \mathrm{mu} \mathrm{g} \mathrm{DDE} / \mathrm{kg}$ (wet weight) in a sea catfish.

\section{Marine paints}

The organotin tributyltin (TBT) is an antifouling biocide used in marine paints and is a common pollutant in harbor estuaries. The immune system of channel catfish previously demonstrated by Regala et al., (2001), Ictalurus punctatus, is a sensitive target organ of TBT. Exposure strongly suppresses humoral immune responses and harbor estuaries often contain polychlorinated biphenyls (PCBs) due to their ubuquitous distribution. The coplanar congener 3,3,4,45-polychlorinated biphenyl (PCB-126) is also immunotoxic to channel catfish, but it suppresses only the innate immune responses and only at high doses.

\section{Role of specific amino acids.}

It is of importance to shed light upon the possibility of the role of specific amino acids such as methionine in the metabolism of DDT, i.e., low levels of methionine resulted in lower levels of DDT and its metabolites accumulating in fish tissues; (Wilcock et al., 1993). On the other hand, Wide spread application of endosulfan as insecticide elicited an aquatic environmental contamination. This organochlorine insecticide is one of the most toxic to fish and since this compound is bioacumulated and tranlocated across trofic chains, its toxic effects may get human populations. (Martinez et al., 1990).

\section{Variations of fish species}

Analytical survey was conducted by Abdallah et al., (1990) for analyzing 15 fish samples representing two different fish species, namely common carb (Cyprinus Carpio) and Tilapia sp (Tilapia Nilotica) as a representative of fresh water fish. The investigated fish samples were exposed to different concentrations of P,P-DDT (organochlorine) and malathion (organophosphorous) for $96 \mathrm{hr}$. Mortality percent, LC50 after 24, 48, 72 and $16 \mathrm{hr}$ of exposure, relative susceptibility (RS), relative Toxicity (RT) and safe concentration (SC) were calculated. The obtained results showed a higher significant difference between the two tested fish species.

\section{REFERENCES}

Abdallah, M.A., Hassan, M.I., Naguib, M.M. \& Abo Donia, M.A. 1990. Analytical survey of organochloring and organophosphorous pesticides in fish samples collected from some Egyptian lakes. International Symposium and Workshop on Food Contamination Mycotoxins and Phycotoxins, Cairo, Egypt, November 4-15, (Abstr.).

Abdel Gawaad, A.A., Shams El-Din, A., \& Ali, M.M. 1989. Pesticide residues and acids in rain water. Pesticide, Environment and Health, $3^{\text {rd }}$ World Conference on Environmental and Health Hazards of pesticides, Cairo, Egypt, December 11-15, 1989 (Abstr.) III-J-O. 
Anonymous 1995. Committee on pesticide residues and related topics. Journal of AOAC. International; 78 (1): 171-177, 210-213.

Askar, A.I. 1980. Water pollution with pesticides: Acute toxicity and residues of pesticides in lake Burullus. M.Sc. Thesis. C.F. Ph.D. Thesis, 1984, Sharaf, I.M., Fac. Agric., Alex. Univ.

Aya, Z., Barlas, N. \& Kolankaya, D. 1997. Determination of organochlorine pesticide residues in various environments and organisms in Goksu Delta, Turkey. Aquat. Toxicel. 39 (2): 171-181.

Barrie, L.A., Gregor, D. \& Hargrave, B. 1992. Arctic contaminants: Sources, occurrence and pathways. Science of the total environment, 122: 1-74.

Burggraaf, S., Wilkins, A.L., Langdon, A.G. \& Wilcock, R.J. 1994. Organochlorine compounds in three species of shellfish from waikareao estuary, tstuary, tauranga harbour newzealand. Bull. Environ. Contam. Toxicol. 57: 111-117.

Chan, H.M. 1998. A database for environmental contaminants in traditional foods in northern and arctic Canada: development and applications. J. Food Additives and Contaminants. 15 (2): 127-134.

Chan, H. M., Berti, P., Peceveur, O. \& Kuhnlein, H.V. 1997. Evaluation of the population distribution of dietary contaminant intakes in an arctic population using bootstrap statistics. Environmental Health Perspectives. 105: 2-7.

Dycus, D.L. \& Lowery, D.H. 1986. Polychlorinated biphenyls (PCB) concentrations in Wilson Reservoir catfish. Tennessee Valley Auth., Knoxville, (USA). Div. p. 44.

Finkel, A.M. 1990. Confronting uncertainty in risk management A guide for decision makers. Resources for the future, Washington, D.C. p. 68.

Galal, G.H. 1991. Dietary intake of pesticide residues: cadmium, mercury, and lead. J. Food-Additives-and-Contaminants, 8 (6): 793-806.

Goodman, L.R., Lewis, M.A., Macauley, J.M., Smith, R.J. \& Moore, J.C. 1999. Preliminary Survey of Chemical Contaminants in Water, Sediment, and Aquatic Biota at Selected Sites in Northeastern Florida Bay and Canal C-111. Gulf of Mexico Science. 17 (1): 1-16.

Helwing, J.T. 1983. SAS Indtroductory guide. Revised Edition SAS Institute Inc. Cary. North Corolina, USA. 27511, pp. 55, 61

Jolllife, J. 1986. Principal component analysis. Springer-Verlage. Berlin.

Jyothi, B. \& Narayan, G. 1999. Certain pesticideinduced carbohydrate metabolic disorders in the serum of freshwater fish Clarias batrachus (Linn.). Food Chem. Toxicol. 37(4): 417-421.
Martens, H. \& Russwurm, H. 1983. Food research and data analysis. Applied Science Publishers, p. 90.

Martinez, T.L., Juarez, C.N., Sanchez, H.E. \& Galar, I. 1990. Endosulfan effect on liver and Gills of the fish Oreochromis Hornorum. International Symposium and Workshop on Food Contamination Mycotoxins and Phycotoxins, Cairo, Egypt, November 4-15, 1990 (Abstr.).

Moilanan, R., Pyysalo, H. \& Kumpulainen, J. 1986. Average total dietary intakes of organochlorine compounds from the Finnish diet. Z. Lebensm unters forsch. 182 : 484488.

Muir, D.C.G., Wagemann, R., Hargrave, B.T., Thomas, D.J., Peakall, D. B. \& Norstrom, R.J. 1992. Arctic marine ecosystem contamination. Science of total environment. 122: $75-134$.

Regala, R.P., Rice, C.D., Schwedler, T.E. \& Dorociak, I.R. 2001. The Effects of Tributyltin (TBT) and 3,3,4,4,5-Pentachlorobiphenyl (PCB-126) mixtures on antibody responses and phagocyte oxidative burst activity in channel catfish, ictalurus punctatus. Arch. Environ. Contam. and Toxicol. 40 (3): 386391.

Roche, H. 2000. Organochlorine residues in European eel (Anguilla anguilla), crucian carp (Carassius carassius) and catfish (Ictalurus nebulosus) from Vaccares lagoon (French National Nature Reserve of Camargue) - effects on some physiological parameters. Aquatic Toxicology. 48 (4): 443-459.

Statsoft. Inc. 1991. "CSS" Package : Complete statistical system. Statsoft Inc., Tulsa, Okla, USA.

Stephen, A.M.,\& Marcia, L.S. 1981. Meat and fish management. Breton Publishers. North Scituate, Massachusetts.

Trivedi, S. \& Saksena, D.N. 1999. Acute toxicity and behavioural response of an organophosphorus pesticide, Nuvan (DDVP) to freshwater catfish Clarias batrachus (Linnaeus). Journal of Environment and Pollution. 6 (1): 53-57.

Vetter, W. \& Luckas, B. 1990. Characteristic chlorinated hydrocarbon patterns in seals from different marine regions. International Symposium and Workshop on Food Contamination Mycotoxins and Phycotoxins, Cairo, Egypt, November 4-15, 1990 (Abstr.).

Wilcock, R.J., Smith, T.J., Pridmore, R.D., Thrush, S.F., Cummings, V.J. \& Hewitt, J.E. 1993. Bioaccumulation and elimination of chlordane by selected intertida benthio fauna. Environ. Toxicol. Chem. 12: 733-742. 


\section{التلوث ببقايا المبيدات فى بعض مصادر الأسماك المختارة}

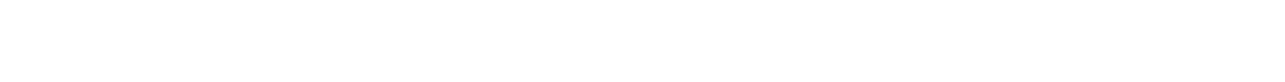

'اقنم الإقتصاد المنزل -كلية التربية النوعية - جلمعة عنش شمس - العبلسية، جمهورية مصر العربية.

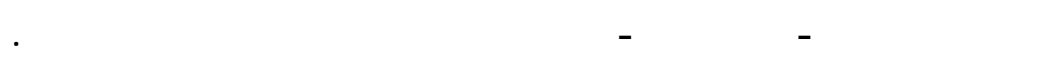
"المعلط المركزية - وزارة الصحة - القاهرة، جمهورية مصر العربية - العزبة.

يتناول هذا البهث ققيم محتوى بعض أنواع الأسمك مل أنواع البياض، البطلى، البورى، الكابوريا، لم

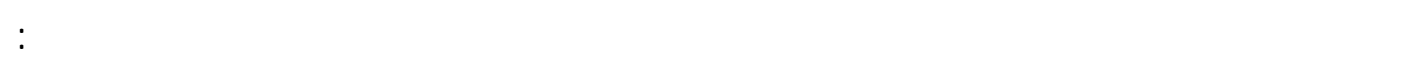
$\alpha$ BHC, $\gamma$ BHC $+\beta$ BHC, Heptachlor, Aldrin, Heptachlor epoxide, $\gamma$ chlordane, $\alpha$ chlordane, P,P-DDE, dieldrin, P,P-DDD, P,P-DDT, endosulfan sulfate, methoxychlor and endrin ketone

لُٔلهرت النتائج المتحطل عليها أن تركيزات الهيدروكربونات الكلورونية فى الأنسجة تعتبر مؤثراً جيداً لمدي

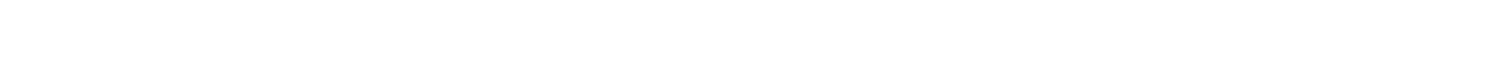

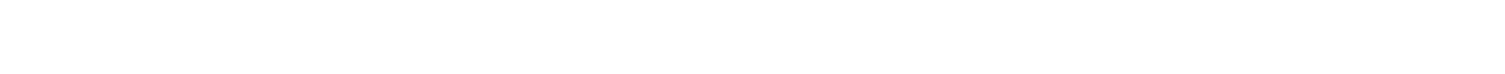

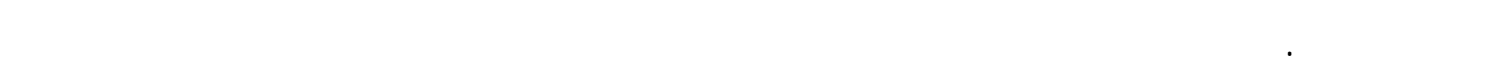

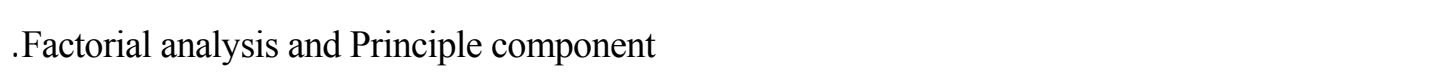

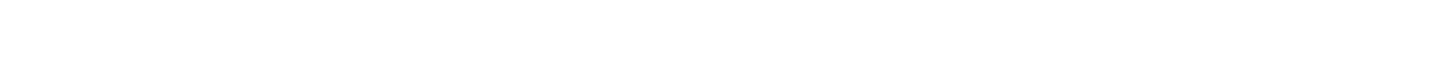

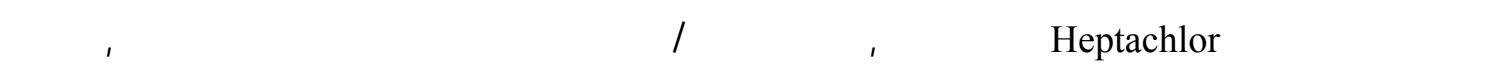

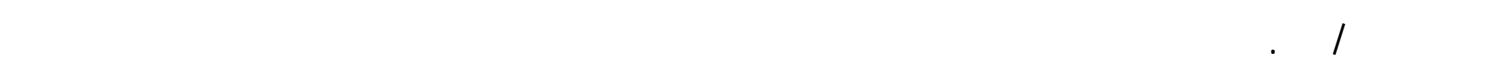

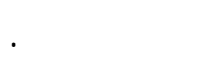

